DOI 10.4467/12332135KRA.21.011.14690

\title{
Działalność popularyzacyjna w Archiwum Narodowym w Krakowie Oddzial w Bochni w 2021 r.
}

W ciągu 70-letniej nieprzerwanej działalności na terenie Bochni - Oddział zaznaczył swoją obecność, uczestnicząc w przygotowywaniu organizowanych na terenie powiatu wystaw historycznych czy sesji naukowych. Pomimo ograniczeń spowodowanych pandemią koronawirusa SARS-CoV-2 pracownicy Oddziału nie zaprzestali działalności również w 2021 r., biorąc udział w wydarzeniach organizowanych przez Urząd Miasta i Gminy Niepołomice oraz Starostwo Powiatowe w Bochni. Kontynuowano także serię Miscellanea Archiwalne w miesięczniku „Kronika Bocheńska”.

4 września br. w sali konferencyjnej Zamku Królewskiego w Niepołomicach miała miejsce uroczysta sesja Rady Miejskiej upamiętniająca Andrzeja Wimmera, pierwszego burmistrza Niepołomic w wolnej Polsce. A. Wimmer pełnił tę funkcję w latach 1921-1930. W 1925 r. zrezygnował wprawdzie z tego stanowiska, ale objął je ponownie w 1927 r. Dzięki jego inicjatywie uruchomiono połączenie kolejowe Kraków-Niepołomice, zwane „Niepołomką" - w dokumencie z 13 lipca 1921 r., przechowywanym w zbiorach bocheńskiego archiwum, A. Wimmer zwraca się z podziękowaniem do dr. Władysława Kiernika, posła ziemi bocheńskiej za pomoc i poparcie starań gminy w sprawie wprowadzenia na kolei ruchu osobowego między Krakowem a Niepołomicami. Przyczynił się również do założenia Miejskiej Szkoły Handlowej oraz do uruchomienia kursów po Wiśle promem pasażerskim.

W programie uroczystości uwzględniono podjecie uchwały w sprawie nadania imienia burmistrza A. Wimmera Parkowi Miejskiemu w Niepołomicach, a także innej, upamiętniającej 30. rocznicę odrodzenia samorządu terytorialnego w Polsce. Podczas sesji uroczyście wręczono medale „Dziękujemy za Wolność” nadane przez Stowarzyszenie Sieć Solidarności pracownikom samorządowym. Po odświętnym odsłonięciu tablicy pamiątkowej w budynku Magistratu zaproszeni goście udali się do Biblioteki Publicznej w Niepołomicach, gdzie odbyło się otwarcie wystawy „Andrzej Wimmer, pierwszy burmistrz Niepołomic w Wolnej Polsce", zorganizowanej we współpracy z Archiwum Narodowym w Krakowie Oddział w Bochni. Przy realizacji wystawy wykorzystano skany materiałów archiwalnych z zespołu 30/8 Akta miasta Niepołomic dotyczących przede wszystkim okresu, kiedy Andrzej Wimmer pełnił funkcje publiczne jako radny, a następnie burmistrz. Przebieg nauki w szkole można było prześledzić na podstawie zaprezentowanych na wystawie skanów dokumentów z zespołu 30/341 Szkoła Ludowa 4-klasowa mieszana w Niepołomicach.

12 września br. pracownicy Oddziału w Bochni wzięli po raz kolejny udział w projekcie „Weekend z Zabytkami Powiatu bocheńskiego” przeprowadzanym corocznie w ramach Europejskich Dni Dziedzictwa. Tym razem wydarzenie w bocheńskim archiwum zorgani- 
zowano pod hasłem: „Obce rzeczy wiedzieć dobrze jest - swoje, obowiązek - Zygmunt Gloger, czyli historie rodzinne w źródle zapisane”.

W czytelni Oddziału zaprezentowano dokumenty stanowiące wyjątkowe świadectwo historii poszczególnych ludzi, rodzin i lokalnych społeczności. Zaproponowano zwiedzającym zapoznanie się z materiałami pochodzącymi wyłącznie ze zbiorów bocheńskiego Archiwum. Dokonując wyboru materiałów, pracownicy pragnęli zwrócić uwagę na ich różnorodność. Obok najstarszych ksiąg miejskich, dokumentów pergaminowych i papierowych prezentowano projekty, plany, widokówki, zdjęcia, afisze i tłoki pieczętne oraz plansze ekspozycyjne wystaw zorganizowanych przez Oddział w poprzednich latach: „Być kobietą... Portrety kobiet ziemi bocheńskiej w wirze życia i dziejów” z 2011 r. i „Historia C.K. Gymnasii Bochniensis" z 2017 r.

Materiały te pozwoliły na zapoznanie się ze źródłami do badań genealogicznych oraz sposobem wyszukiwania w nich informacji. Pracownicy Oddziału doradzali, jak najprościej zabezpieczać swoje archiwa rodzinne, aby jak najdłużej służyły kolejnym pokoleniom. Zaproszono również do wysłuchania, na świeżym powietrzu, opowieści o historii willi „Pod Kozłem” projektu Teodora Talowskiego (obecnej siedziby Oddziału) oraz losach jej rodziny. Historie przybliżyły zwiedzającym pracownice Oddziału: Agnieszka Gicala i Dorota Szymczyk. Najmłodsi mogli wcielić się w rolę „,małego archiwisty” polegającą na odkrywaniu magazynów archiwalnych, wyszukiwaniu informacji w dokumentach na temat przodków czy odwzorowywaniu filigranów zachowanych w księgach staropolskich.

We wrześniu ubiegłego roku, w związku z 70. urodzinami bocheńskiego Oddziału, w miesięczniku „Kronika Bocheńska” zapoczątkowano cykl Miscellanea Archiwalne, w którym prezentowane są wyjątkowe zasoby Oddziału. Są one bardzo zróżnicowane, zawierają materiały aktowe, afisze, druki ulotne, dokumentację fotograficzną, techniczną i kartograficzną, warte przybliżenia czytelnikom. Na łamach czasopisma opowiadamy też historie związane z przekazaniem materiałów ze zbiorów prywatnych do zasobu Archiwum. W 2020 r. ukazały się artykuły: o historii budynku (obecnej siedziby Archiwum) oraz losach rodziny Sillberingów O lwie, który strzeże archiwaliów $w^{1}$; o zasobie staropolskim Najstarsze księgi ${ }^{2}$; o genealogii Genos - ród, logos - wiedza $a^{3}$; o archiwach rodzinnych Pamiatka dla przyszłych pokoleń ${ }^{4}$. W 2021 r. przygotowane zostały artykuły: o losach dokumentacji fotograficznej rodziny Karpff Historia pudetka ze zdjęciami ${ }^{5}$; o wystawie „Kazimierz - sławny i z czynów Wielki", przygotowanej w 2010 r. przez Archiwum Narodowe w Krakowie i materiałach archiwalnych z zasobu Oddziału upamiętniających osobę króla Kazimierza

${ }^{1}$ Agnieszka Gicala, O lwie, który strzeże archiwaliów, „Kronika Bocheńska” 2020, nr 9 (338), R. 28, s. 49-51.

${ }^{2}$ Eadem, Najstarsze księgi, „Kronika Bocheńska” 2020, nr 10 (339), R. 28, s. 22-24.

${ }^{3}$ Eadem, Genos - ród, logos - wiedza, „Kronika Bocheńska” 2020, nr 11 (340), R. 28, s. 34-36.

${ }^{4}$ Eadem, Pamiątka dla przysztych pokoleń, „Kronika Bocheńska” 2020, nr 12 (341), R. 28, s. $37-40$.

${ }^{5}$ Eadem, Pudełko ze zdjęciami, „Kronika Bocheńska” 2021, nr 1-2 (342-346), R. 29, s. 32-34. 
Wielkiego pod tym samym tytułem Kazimierz - sławny i z czynów Wielki ${ }^{6}$; o działalności Oddziału w Bochni Po co komu archiwum??7; o świętach majowych Majowe świętowanie ${ }^{8}$; o Międzynarodowym Dniu Dziecka Wielkie święto małego człowieka ; o sposobie spędzania wolnego czasu Wyjechali na wakacje wszyscy nasi podopieczni ${ }^{10}$; o aktach szkolnych z zasobu Oddziału To już jest koniec, nie ma już nic, znowu do szkoły musimy iśćc ${ }^{11}$; o Dniu Nauczyciela Święto przy tablicy ${ }^{12}$.

Agnieszka Gicala Archiwum Narodowe w Krakowie

${ }^{6}$ Eadem, Kazimierz - stawny i z czynów Wielki, „Kronika Bocheńska” 2021, nr 3 (343), R. 29, s. 20-25.

${ }^{7}$ Eadem, Po co komu archiwum?, „Kronika Bocheńska” 2021, nr 4 (344), R. 29, s. 35-39.

${ }^{8}$ Eadem, Majowe świętowanie, „Kronika Bocheńska” 2021, nr 5 (345), R. 29, s. 28-32.

${ }^{9}$ Eadem, Wielkie święto małego człowieka, „Kronika Bocheńska” 2021, nr 6 (346), R. 29, s. $28-29$.

${ }^{10}$ Eadem, Wyjechali na wakacje wszyscy nasi podopieczni, „Kronika Bocheńska” 2021, nr 7-8 (347-348), R. 29, s. 33-36.

${ }^{11}$ Eadem, To już jest koniec, nie ma już nic znowu do szkoty musimy iść, „Kronika Bocheńska” 2021, nr 9 (349), R. 29, s. 36-40.

${ }^{12}$ Eadem, Święto przy tablicy, „Kronika Bocheńska” 2021, nr 10 (350), R. 29, s. 31-34. 